\title{
VARIABILITY AND INTRASPECIES CLASSIFICATION OF PUMKIN (Cucurbita moschata (Duch. ex Lam.) Duch. ex Poir.) BASED ON MORPHOLOGICAL CHARACTERS
}

\author{
Purnomo ${ }^{1}$, Budi Setiadi Daryono², and Maulidya Beta Sentori ${ }^{1}$ \\ ${ }^{1}$ Laboratory of Plant Sistematic, Faculty of Biology, Gadjah Mada University. \\ ${ }^{2}$ Laboratory of Genetic, Faculty of Biology, Gadjah Mada University.
}

\begin{abstract}
Pumpkin (C. moschata) is minor cultivated plant has morphological variability, that is. important data illustrate the genetic variability. Morphological variation data of of pumpkin can be used for intraspecies classification and conservation. The relationship of cultivar groups of pumpkin also as important data for pumpkin cultivation. The objectives of this study are to determine variability and intraspecies classification of pumpkin in Yogyakarta and around area based on morphological characters. Cultivar accession are collected from Yogyakarta, and Kopeng also Salatiga central Java as operational taxonomic units (OTU's). Character scoring based on IPGRI of pumpkin with soft modification. Morphological similarity is calculated based on presence and absence characters, and cluster analysis is conducted by UPGMA method to create dendrogram to determine morphological variability and intraspecies classification of pumpkin based on morphological similarity. The result study shows, that there are 3 fruit shapes, namely giant, globular, and oblong with lobes or not. Pumpkin also has yellow and orange colors fruit flesh. The taste of fruit flesh are sweet or not. Based on Dendrogram pumpkin is classified into 3 group cultivars: lowland group with standard fruit shape, highland with standard fruit shape, and giant cultivar groups. Morphological variability of pumpkin in Yogyakarta and around areas indicate on fruit shape, fruit size, fruit color, and taste of fruit flesh, with morphological similarity coefficient 0,55-0,88.
\end{abstract}

Key words: C. moschata, cultivar, morphological variability, intraspecies classification, phenetic relationship.

\section{INTRODUCTION}

The native country of pumpkin (C. moschata) is unknown, in Java cultivated or as an escape in waste places (Backer \& Brink, 1963), and the common name of pumpkin in Java is waluh. It was thought that $C$. moschata, like Cucurbita ficifolia, was of Asiatic origin. However, it is now evident that it was domesticated in Latin America, although it is still unclear what the precise area of domestication of either species was (Bermejo \& Leon, 1994). Central Mexico is the centre of origin of $C$. moschata (Annonymus, 2013).

Pumpkin is the common vegetable in the tropic and sub-tropic country, in Bangladesh popularity of pumpkin equal with terung and lobak. There are many pumpkin cultivars in the world, and the whole fruit of pumpkin can be keep along 6 mounts, before consumption (Rafique et al., 2011).

Morphological variation of $C$. moschata are in fruit shape and the color of fruit flesh. Fruit shape are globular, flattened, cylindrical, oval, turbinate, curved crooked neck, pyriform, dumbbell, or elongated. Variation also indicated on the thickened of fruit flesh, the color of fruit skin, the color of fruit flesh, and a number of fruit groove. In the young fruits the color of fruit surface are green or yellowish red, and the color of fruit flesh are yellow or orange (Alcazar \& Gulick, 1983). Intraspecies classification of $C$. moschata based on the fruit characters is importance to do for cultivation especially for seed selection (Bermejo \& Leon, 1994). 
According Sanjur et al. (2002) C. moschata is diverse in terms of species based on mitochondrial genes, the plant has many cultivars.

Pumpkin in Java has many fruit shapes, and the color of fruit surface and fruit flesh. Fruit flesh has difference thickness about $3 \mathrm{~cm}$ with sweetish taste. Fruit commonly $3-5 \mathrm{~kg}$, and the weight of fruit to reach for $20 \mathrm{~kg}$. Fruit with thick skin using for pursue the respiration and transpiration. Plant breeding can be started from the selection of genetic diversity in a crop species, selecting the best variety for cross mains, to create cultivars that have high production, disease resistance, with vigorous growth (Tsivelikas et al., 2009; Ahira, 2011).

This biosystematics study of $C$. moschata will express the variation and to determine the intraspecies classification based on morphological characters. Morphological variability is important data illustrate the genetic variability. This study are importance to identify range of variation and morphological similarity among accession using cluster analysis. The result useful for identification of characters selection on pumpkin cultivation and conservation. The Selection of parental character pumpkin is also important to determine the nature of the cultivar to be formed.

\section{MATERIALS AND METHODS}

Sample or accession collection conducted by survey method in pumpkin cultivation center in Yogyakarta and surrounding areas. There are a number of 22 accessions that can be compared in this study. A sample of pumpkin are leaves, flowers, fruits, and seeds. Operational taxonomic units (OTU's) in this study is the pumpkin plant accessions. Species identification was based on the identification key. Morphological characterization is done by coding and scoring is based on the IPGRI (Alcazar \& Gulick, 1983) with soft modifications. The observed morphological characters are leaves, flowers, fruits, and seeds (Table 1). Scoring data is standardized to establish the present and absence character tables. Based on the table the similarity index among accessions is calculated using Jaccard formula (Sokal \& Sneath, 1963). Qualitative morphological data were analyzed descriptively to obtain characteristic of pumpkin accessions. Cluster analysis conducted based on similarity index with Unweighted Pair-Group Method Using Arithmetic Average (UPGMA) method to create a dendrogram using Numerical taxonomy and Multivariate Analysis System (NTSYSpc2.1) software (Rohlf, 1993).

Tabel 1. Scoring and coding morphological charaters base on IPGRI

\begin{tabular}{lll}
\hline No. & Morphological Characters & Scoring \\
\hline 1 & Color of upper surface leaf & $0=$ green, $1=$ pale green, $2=$ Yellowish green \\
2 & Color of under surface leaf & $0=$ green, $1=$ pale green, $2=$ yellowish green \\
3 & Length of leaf blade & $0=1-9 \mathrm{~cm}, 1=10-19 \mathrm{~cm}, 2=20-29 \mathrm{~cm}$. \\
4 & Width of laf blade & $0=1-9 \mathrm{~cm}, 1=10-19 \mathrm{~cm}, 2=20-29 \mathrm{~cm}$. \\
5 & Length of leaf petiole & $0=1-12 \mathrm{~cm} ., 1=13-22 \mathrm{~cm}$. \\
6 & Color of petals & $0=$ yellow, $1=$ dark yellow \\
7 & Flowers length & $0=0-6.0 \mathrm{~cm}, 1=6.5-12 \mathrm{~cm}$. \\
8 & Fruit shape & $0=$ Spheris, $1=$ flattened, $2=$ cylindrical, $3=$ \\
& Dominant color of fruit skin & heart shape, $4=$ pyriform, $5=$ oblong \\
9 & De yellow, $1=$ pale yellow, $2=$ orange, $3=$ \\
& & green, $4=$ yellowish green, $5=$ greenish \\
& orange, $6=$ dark green, $7=$ cream, $8=$ light \\
& brown, $9=$ gold
\end{tabular}




\begin{tabular}{|c|c|c|}
\hline No. & Morphological Characters & Scoring \\
\hline 10 & Secondary color of fruit skin & $\begin{array}{l}0=\text { orange }, 1=\text { dark orange, } 2=\text { pale orange, } \\
3=\text { green, } 4=\text { pale green, } 5=\text { yellow, } 6=\text { dark } \\
\text { yellow, } 7=\text { gold brown. }\end{array}$ \\
\hline 11 & Color pattern of skin fruit & $\begin{array}{l}0=\text { none, } 1=\text { crem spot, } 2=\text { green spot, } 3= \\
\text { orange spot, } 4=\text { yellow nodule, } 5=\text { brown } \\
\text { nodule, } 6=\text { orange shades, } 7=\text { cream } \\
\text { shades. }\end{array}$ \\
\hline 12 & Texture of fruit skin & $\begin{array}{l}0=\text { no grooves, } 1=\text { very soft grooves, } 2=\text { soft } \\
\text { grooves, } 3=\text { hard grooves, } 4=\text { very har } \\
\text { grooves }\end{array}$ \\
\hline 13 & Number of fruit grooves & $0=0-3,1=4-6,2=7-9,3=10-12$ \\
\hline 14 & Fruit length & $\begin{array}{l}0=1-15 \mathrm{~cm}, 1=16-30 \mathrm{~cm}, 2=31-45 \mathrm{~cm}, \\
3=46-60 \mathrm{~cm} .\end{array}$ \\
\hline 15 & Fruit width & $0=1-10 \mathrm{~cm}, 1=11-20 \mathrm{~cm}, 2=21-30 \mathrm{~cm}$. \\
\hline 16 & Circumference of fruit & $0=0-30 \mathrm{~cm}, 1=31-60 \mathrm{~cm}, 2=51-90 \mathrm{~cm}$ \\
\hline 17 & Flesh fruit color & $\begin{array}{l}0=\text { red Salem, } 1=\text { yellow, } 2=\text { pale yellow, } 3= \\
\text { dark yellow, } 4=\text { pale orange, } 5=\text { orange, } 6= \\
\text { dark orange. }\end{array}$ \\
\hline 18 & Fruit surface & $0=$ smooth, $1=$ rough \\
\hline 19 & Texture of skin fruit & $0=$ soft, $1=$ hard, $2=$ very hard \\
\hline 20 & Seed color & $\begin{array}{l}0=\text { white }, 1=\text { white ash, } 2=\text { cream, } 3=\text { light } \\
\text { brown, } 4=\text { pale cream }\end{array}$ \\
\hline 21 & Edge of the seed layer color & $\begin{array}{l}0=\text { cream, } 1=\text { pale cream, } 2=\text { dark cream, } \\
3=\text { light brown }\end{array}$ \\
\hline 22 & Seed thickness & $0=$ thin, $1=$ thick \\
\hline 23 & Seed surface & $\begin{array}{l}0=\text { smooth }, 1=\text { smooth shiny, } 2=a \text { bit rough, } \\
3=\text { rough }\end{array}$ \\
\hline 24 & Fruit flesh taste & $0=$ tasteless, $1=$ sweetish, $3=$ sweet. \\
\hline
\end{tabular}

\section{RESULT AND DISCUSSION}

\section{A. Morphological Variability}

Genetic variability of pumpkin based on morphological characters appear dominantly on the fruit than on leaves, flowers, and seeds.

\section{Leaves}

According to Bermejo \& Leon (1994), pumpkin leaves have petioles of $30 \mathrm{~cm}$ or more, are broadly ovate-cordate to suborbicular, measure 20 to $25 \times 25$ to $30 \mathrm{~cm}$, have white spots, are slightly lobate with three to five ovate or triangular lobules. have an obtuse apex that is briefly apiculate, serrate-denticulate margins and three to five ramified tendrils. Pumpkin leaves from Yogyakarta and surrounding areas are single leaf, petiole as long as the leaf blade, petiole surface hairy, ovate to cordate leaf blade, short tapered tip (apiculate), 7-35 $\mathrm{cm}$ long, 6-30 $\mathrm{cm}$ wide, the surface of the blade is completed with a sharp hair-shaped trichome. Morphological variability of leaves is found in the depth of incise margin.

\section{Flower}

C. moschata is a monoecious plant, and has male (staminate) and female (pistilate) flowers in one individual plant. C. moschata has pentamerous, solitary, axillaries flowers. The male flowers have 16 to $18 \mathrm{~cm}$ pedicels and a very short calyx, are broadly campanulate to pateriform, expanded or foliaceous towards the apex, 5 to $13.5 \mathrm{~cm}$ long, with five divisions for up to one-third of their length. Staminate flower has 5 sepals pale green, attaches at 
the base, 5 synanthera stamens, anthers triangular sharp-pointed. The female flowers have thick pedicels of 3 to $8 \mathrm{~cm}$ in length, and a globose, ovoid, oblate, cylindrical, pyriform, conical, turbinate ovary. They have a very small calyx and sepals that are more often foliaceous than in the males, measure up to $7.5 \mathrm{~cm}$ in length and are of thickened style. They have three lobately stigmas.

\section{Fruit}

The fruit varies greatly in size and shape (generally following the form of the ovary): smooth or with rounded ribs, rarely verrucose or granulose, with a rind that is both thickened and durable and soft and smooth, and of a very variable color, light green to uniform dark green or with cream spots, light to dark, or completely white. The flesh is light or bright orange to greenish, ranges from light to very sweet, is soft and generally not fibrous. In the study area was found 7 fruit shape, surface color green to yellow rind with a variety of color patterns. Fruit flesh pale yellow to orange (Figure 1.a).

\section{Seed}

It has numerous seeds which are ovate/elliptical, measuring 8 to $21 \times 5$ to $11 \mathrm{~mm}$ and which have a yellowish-white surface (Figure 1.b). Usefulness of pumpkin seeds are informed by Arnita \& Yurinda (2004) that in the pharmaceutical field pumpkin seeds contain laxative and anthelmitic substances

\section{B. Cluster Analysis}

\section{Accessions of C. moschata}

A total of 22 accessions of $C$. moschata collected from pumpkin cultivation center in Yogyakarta and Salatiga (Kopeng and Klero). Sample collection indicate to the variation of fruit morphology, local name, and the use by user community. Information on fruit shape, fruit skin color, flesh color of fruit, seeds, and fruit flavors can be seen in Table 2.

Table 2. Accessions number, local names, location, and fruit characters

\begin{tabular}{|c|c|c|c|c|}
\hline No. & $\begin{array}{l}\text { Accession } \\
\text { number }\end{array}$ & Local name & Location & $\begin{array}{l}\text { Fruit characters } \\
\text { (fruit shape, fruit flesh color, } \\
\text { texture of fruit flesh, skin fruit } \\
\text { color, seed color, taste of fruit } \\
\text { flesh) }\end{array}$ \\
\hline 1 & 01-TTBIO & Waluh bokor & $\begin{array}{l}\text { Bantul, } \\
\text { Yogyakarta }\end{array}$ & $\begin{array}{l}\text { Flattened, orange (red salmon), } \\
\text { hard, yellowish red, cream, no taste. }\end{array}$ \\
\hline 2 & 02-TTBIO & Waluh & $\begin{array}{l}\text { Bantul, } \\
\text { Yogyakarta }\end{array}$ & $\begin{array}{l}\text { Flattened, yellow, soft, yellowish } \\
\text { red, yellowish white, no taste. }\end{array}$ \\
\hline 3 & 03-TTBIO & Waluh & $\begin{array}{l}\text { Bantul, } \\
\text { Yogyakarta }\end{array}$ & $\begin{array}{l}\text { Rounded, yellow, soft, yellowish } \\
\text { red, yellowish white, sweetish. }\end{array}$ \\
\hline 4 & 04-TTBIO & Waluh & $\begin{array}{l}\text { Bantul, } \\
\text { Yogyakarta }\end{array}$ & $\begin{array}{l}\text { Hearth shape, orange, soft, } \\
\text { yellowish red, yellowish white, } \\
\text { sweetish. }\end{array}$ \\
\hline 5 & 05-TTBIO & Waluh & $\begin{array}{l}\text { Bantul, } \\
\text { Yogyakarta }\end{array}$ & $\begin{array}{l}\text { Hearth shape, orange, soft, } \\
\text { yellowish red, yellowish white, no } \\
\text { taste. }\end{array}$ \\
\hline 6 & 06-TTBIO & Waluh & $\begin{array}{l}\text { Bantul, } \\
\text { Yogyakarta }\end{array}$ & $\begin{array}{l}\text { Rounded, orange, hard, yellowish } \\
\text { red, yellowish white, sweet.. }\end{array}$ \\
\hline 7 & 07-TTBIO & Waluh & $\begin{array}{l}\text { Bantul, } \\
\text { Yogyakarta }\end{array}$ & $\begin{array}{l}\text { Cylindrical, orange, soft, yellowish } \\
\text { red, yellowish white, no taste }\end{array}$ \\
\hline
\end{tabular}




\begin{tabular}{|c|c|c|c|c|}
\hline No. & $\begin{array}{l}\text { Accession } \\
\text { number }\end{array}$ & Local name & Location & $\begin{array}{l}\text { Fruit characters } \\
\text { (fruit shape, fruit flesh color, } \\
\text { texture of fruit flesh, skin fruit } \\
\text { color, seed color, taste of fruit } \\
\text { flesh) }\end{array}$ \\
\hline 8 & 08-TTBIO & Waluh & $\begin{array}{l}\text { Kopeng, Salatiga, } \\
\text { Central Java }\end{array}$ & $\begin{array}{l}\text { Cylindrical, dark orange, hard, } \\
\text { yellowish red, yellowish white, } \\
\text { sweet. }\end{array}$ \\
\hline 9 & 09-TTBIO & Waluh & $\begin{array}{l}\text { Kopeng, Salatiga, } \\
\text { Central Java }\end{array}$ & $\begin{array}{l}\text { Pyriform, dark yellow, soft, yellowish } \\
\text { white, no taste. }\end{array}$ \\
\hline 10 & 10-TTBIO & Waluh & $\begin{array}{l}\text { Kopeng, Salatiga, } \\
\text { Central Java }\end{array}$ & $\begin{array}{l}\text { Oblong, orange, hard, yellowish } \\
\text { green, yellowish white, sweetish. }\end{array}$ \\
\hline 11 & 11-TTBIO & Waluh & $\begin{array}{l}\text { Sleman, } \\
\text { Yogyakarta }\end{array}$ & $\begin{array}{l}\text { Oblong, dark orange, soft, yellowish } \\
\text { green, yellowish white, sweet. }\end{array}$ \\
\hline 12 & 12-TTBIO & Waluh & $\begin{array}{l}\text { Sleman, } \\
\text { Yogyakarta }\end{array}$ & $\begin{array}{l}\text { Oblong, pale orange, soft, yellowish } \\
\text { green, yellowish white, no taste. }\end{array}$ \\
\hline 13 & 13-TTBIO & Waluh & $\begin{array}{l}\text { Kopeng, Salatiga, } \\
\text { Central Java }\end{array}$ & $\begin{array}{l}\text { Spheris, red salmon ( dark orange), } \\
\text { soft, yellowish green, yellowish } \\
\text { white, sweet. }\end{array}$ \\
\hline 14 & 14-TTBIO & Waluh tegil & $\begin{array}{l}\text { Kopeng, Salatiga, } \\
\text { Central Java }\end{array}$ & $\begin{array}{l}\text { Oblong, pale orange, soft, yellowish } \\
\text { green, yellowish white, no taste. }\end{array}$ \\
\hline 15 & 15-TTBIO & Waluh tegil & $\begin{array}{l}\text { Kopeng, Salatiga, } \\
\text { Central Java }\end{array}$ & $\begin{array}{l}\text { cylindrical, orange, soft, yellowish } \\
\text { green, yellowish white, sweet. }\end{array}$ \\
\hline 16 & 16-TTBIO & Waluh & $\begin{array}{l}\text { Klero, Salatiga, } \\
\text { Central Java }\end{array}$ & $\begin{array}{l}\text { Spheris, dark yellow, soft, yellowish } \\
\text { green, yellowish white, sweet. }\end{array}$ \\
\hline 17 & 17-TTBIO & Waluh & $\begin{array}{l}\text { Klero, Salatiga, } \\
\text { Central Java }\end{array}$ & $\begin{array}{l}\text { Heart shape, pale orange, hard, } \\
\text { yellowish green, yellowish white, no } \\
\text { taste. }\end{array}$ \\
\hline 18 & 18-TTBIO & Waluh & $\begin{array}{l}\text { Klero, Salatiga, } \\
\text { Central Java }\end{array}$ & $\begin{array}{l}\text { Flattened, pale yellow, hard, } \\
\text { yellowish green, yellowish white, no } \\
\text { taste. }\end{array}$ \\
\hline 19 & 19-TTBIO & Waluh & $\begin{array}{l}\text { Klero, Salatiga, } \\
\text { Central Java }\end{array}$ & $\begin{array}{l}\text { cylindrical, pale orange, hard, } \\
\text { yellowish green, yellowish white, no }\end{array}$ \\
\hline 20 & 20-TTBIO & Waluh & $\begin{array}{l}\text { Kopeng, Salatiga, } \\
\text { Central Java }\end{array}$ & $\begin{array}{l}\text { Pyriform, red salem (dark orange), } \\
\text { soft, yellowish green, yellowish } \\
\text { white, no taste. }\end{array}$ \\
\hline 21 & 21-TTBIO & Waluh & $\begin{array}{l}\text { Bantul, } \\
\text { Yogyakarta }\end{array}$ & $\begin{array}{l}\text { Spheris, yellow, soft, yellowish } \\
\text { green, yellowish white, no taste. }\end{array}$ \\
\hline 22 & 22-TTBIO & Waluh & $\begin{array}{l}\text { Kopeng, Salatiga, } \\
\text { Central Java }\end{array}$ & $\begin{array}{l}\text { Cylindrical, pale orange, hard, } \\
\text { yellowish green, yellowish white, } \\
\text { sweet. }\end{array}$ \\
\hline
\end{tabular}

\section{Morphological Variability and Intraspecies Classification}

Dendrogram (Figure 2.) was created based on morphological similarity index (Jaccard) (Sokal \& Sneath, 1963) and UPGMA cluster analysis, with NTSYSpc 2.1 (Rohlf, 1993) software. Furthermore, from 36 characters observed only 24 morphological characters can be compared. The dominance characters that affected to the dendrogram are the fruit shape, fruit surface color, and fruit flesh color.

Dendrogram (Figure 2) shows that the pumpkin has a high morphological variability with similarity coefficients ranging from 0.29 to 0.83 , it is in line with the opinion of sigh (1999). The wide range of altitudes at which C. moschata is cultivated within the American continent, the considerable morphological diversity of its seeds and fruit (colour, shape, thickness and durability of the fruit's skin), the existence of varieties with life cycles of different duration as well as the existence of numerous cultivars developed in other parts of the world and of local varieties with excellent agronomic characteristics, clearly indicate that the genetic variation of this species is very extensive. This is in accordance with the opinion Saade \& Hernandez (1994). As crop cultivation C. moschata in the world until now has approximately 62 cultivars (Robinsons, 2012). 


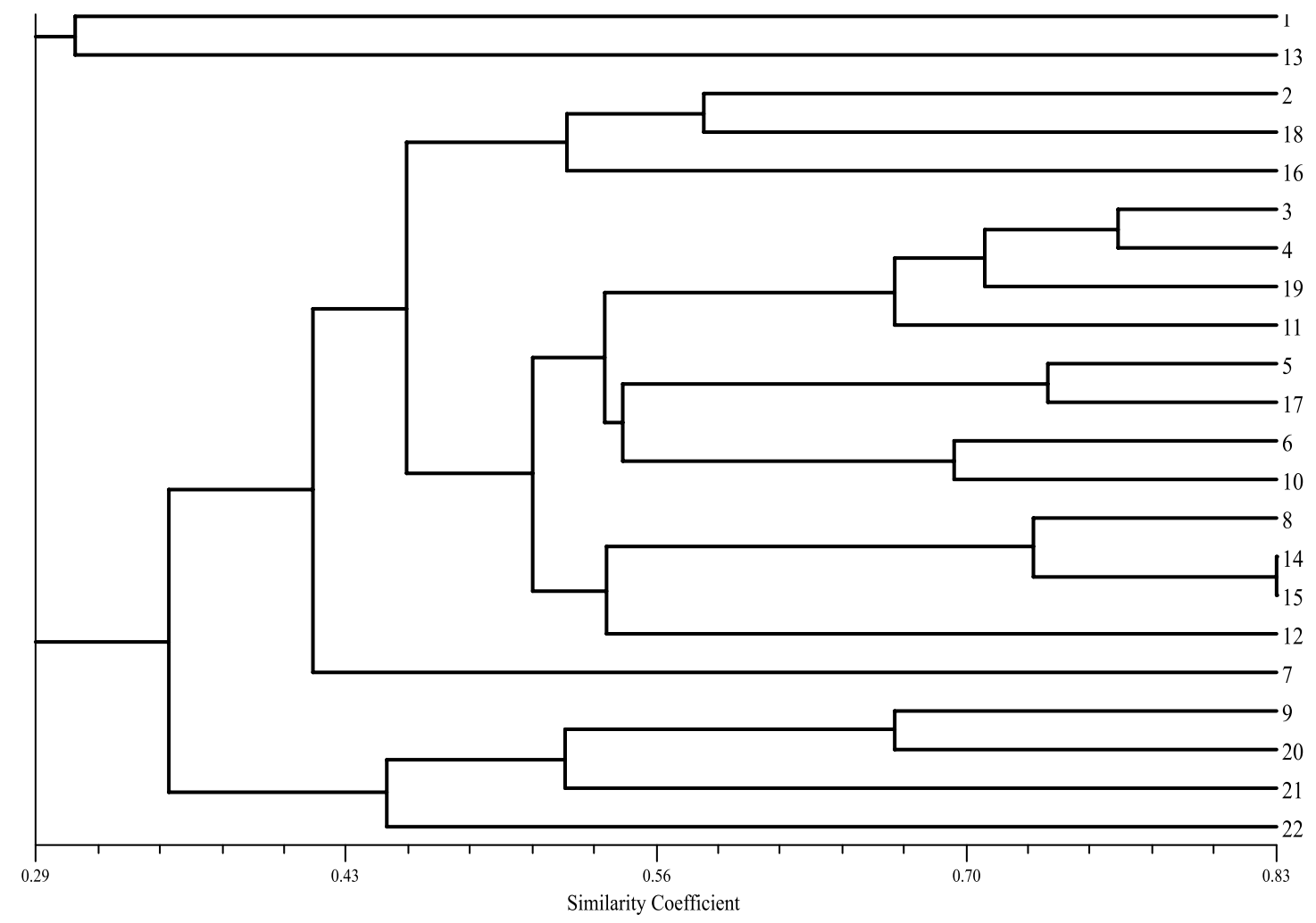

Figure 2. Dendrogram shown the morphological variability and intraspecies classification of C. moschata accession in Yogyakarta and surrounding areas. The righ number is OTU's

Dendrogram divided into two clusters $\mathrm{A}$ and $\mathrm{B}$. The A cluster consists of accession numbers 1 and 13 with 0.3 similarity coefficient, both have similarities fruit flattened shape, has red salmon fruit flesh color, and the surface of the fruit has a number of grooves. Accession 13 origin of Kopeng, Salatiga, Central Java is a giant pumpkin. Cluster B consisted of accessions with diverse characters, the cluster is then divided into clusters a and $b$. Red salmon on the flesh of the fruit attractive to health, because the content of pumpkin flesh is the most dominant $\beta$ carotene and vitamin $A$ in addition to the vitamin $C$ (Arninda \& Yurinda, 2004; Astawan, 2004).

The a cluster consists of accession numbers 2, 3, 4, 5, 6, 7 (Bantul, Yogyakarta), 11, 12, 19 (Sleman, Yogyakarta), 8, 10, 14, 15 (Kopeng, Salatiga), 16, 17, 18 (Klero, Salatiga) clustered at similarity coefficient of 0.40 . The entire accessions have low morphological similarities in terms of surface grooves are not real fruit with greenish color, in this group have a high fruit shape variation is of globular shape, ellipsoid, and heart,. This cluster also has a flesh color and thickness varies, but the color is yellow patterned. At this cluster accession numbers 3-4-11-19, 5-17, and 8-14-15 have high morphological similarities with similarity coefficients between 0.69 to 0.83 , it can be caused because seed comes from the same parent who has experienced cross-pollination with other individuals. Morphological similarity coefficient in this study did not reach to 1 , because pumpkin cannot be propagated vegetatively (clone). This is consistent with research Gwanama et al. (2000) which states that pumpkin cultivars with molecular RAPD analysis are diverse and cannot be propagated vegetatively. 
Cluster $b$ consists of an accession number 9, 20, 22 (Kopeng, Salatiga), and 21 (Bantul, Yogyakarta) all clustered at a similarity coefficient of 0.50 , this cluster has morphological similarities on cylindrical to dumbbell fruit shape (elongate) with pale yellow flesh color.

\section{CONCLUSION}

Morphological variability of $C$. moschata in Yogyakarta and surrounding area is enough high, indicate to fruit shape, fruit color, and color of fruit flesh. Morphological variability of pumpkin has coefficient similarity range from 0.29 to 0.83 . Intraspesies classification base on fruit shape and fruit flesh color and clasiified in to 3 groups accessions i.e. (1) flattened fruit shape with red Salem fruit flesh pumpkin, (2) oblong to Spheris shape with yellow to orange fruit flesh, and (3) cylindrical or dumbbell shape with pale yellow fruit flesh.

\section{ACKNOWLEGMENT}

We would like to thank to Faculty of Biology, Gadjah Mada University Indonesia for supporting financial through Research Grant No: UGM/BI/2455/M/ 05/01.

\section{REFFERENCES}

Ahira, A. 2011. Pemuliaan Tanaman. http://anneahira.com/pemuliaan-tanaman.htm. accessed February 13, 2012.

Alcazar and Gulick, 1983. Minimum descriptors for Cucurbita spp., cucumber, melon and watermelon. ECPGR Working Group on Cucurbits, August 2008

Annonymus. 2013. Cucurbita moshata (Duch. ex Lam.) Duch. ex Poir. (Cucurbitaceae). http://www.lobinmed.com/index.php?option=com_content\&view=article\&id=62859: Cucurbita.

Arninda, M.P., and A.P. Yurinda, 2004. Ekstraksi dan Pengeringan Waluh Untuk Mendapatkan Produk Fine Powder. Skripsi, Jurusan Teknik Kimia, Fakultas Teknik Universitas Diponegoro. Pp: 1-6

Astawan M., 2004. Labu Kuning Penawar Racun dan Cacing Pita Yang Kaya Antioksidan. http://www.gizi.net/cgibin/berita/fulnews.cgi?newsid 10817442482,71695. Accessed February 12, 2012.

Backer, C.A., and R.C. Bakhuizen v.d. Brink, 1963. Flora of Java. Vol. III. N.V.P. Noordhoff, NV-Groningen, The Netherlands.

Bermejo J.E.H. \& J. Leon, 1994. Plant Production and Protection Series . FAO, Rome, Italy. 26: 63-77.

Gwanama, C., M.T. Labuschagne, and A.M. Botha, 2000. Analysis of genetic variation in Cucurbita moschata by random amplified polymorphic DNA (RAPD) markers. Euphytica 113:19-24.

Rafique N., S. H. Raza, M. Qasim, and N. Iqbal. 2011. Pre-Showing Application of Ascorbic Acid and Slaicilic Aacid to Seed of Pumpkin and Seedling Responces to Salt. Pak. J. Bot 43(6): 2677-2682

Rohlf, F.J., 1993. NTSYSpc2.1 Numerical Taxonomy and Multivariate Analysis System Version 2. 1. User Guide. Department of Ecology and Evolution State University of New York Stony Brook, NY 11794-5245. 
Saade, R.L., and S.M. Hernandez, 1994. Cucurbits (Cucurbita spp.). Plant Production and Protection Series No. 26. FAO, Rome, Italy. p. 63-77.

Sanjur, O.L., D.R. Piperno, T.C. Andres, and L.W. Beaver, 2002. Phylogenetic Relationships Among Domesticated and Wild Species of Cucurbita (Cucurbitaceae) Inferred from a Motochondrial Gene: Implication for Crop Plant Evolution and Areas Origin. PNAS. 99 (1): 535-540.

Sokal, R.R., and P.H.A. Sneath. 1963. Principles of Numerical Taxonomy. W.H. Freeman and Company. San Fransisco and London. P: 60-166.

Tsivelikas, A.L., K. Olga, A. Anastasia, N.S George, A. Ekaterini, T. Mavrona, and K.S. Metaxia. 2009. Description and Analysis of Genetic Diversity Among Squash Accessions. International Journal Brazilian Archives Biology and Technology. 52 (2): 271-283. 